\title{
PD- 3
}

\section{尿路画像診断における最新技術}

東京慈恵会医科大学泌尿器科

大石幸彦

泌尿器科臨床の場において画像診断法、特に断層画像診断は腫瘍の存在、質 的、周囲臓器との位置関係（拡がり）を把握することにより、治療方針の決定、 術後の経過観察、治療の評価、再発、予後判定に際し中心的な役割を担ってい る。

X線の発見後の 1 世紀の間に多くの先人の努力、研究により尿路画像診断法は 著しく進歩、発展を遂げてきた。超音波診断をはじめX線CT、MRIにみられる 断層画像法の急速な進歩、普及に加えて造影剤の開発による貢献は極めて大き い。超音波診断においても超音波用造影剤の検討もなされている。さらにへリ カルCT、MRIでの高速撮影法の普及により、撮影時間は短縮され、腹部MRI は血管の呼吸停止下撮像も容易となり、良質の画像が得られ、診断精度増した。 ヘリカルCT、MRIは血管の描出に優れ、泌尿器科腫瘍、腎損傷に対する血管 造影法はTAE、抗癌剂局所注入療法などを前提とした特殊な場合を除き、行わ れない傾向にある。

また、multi-detector row $\mathrm{CT}(\mathrm{MD}-\mathrm{CT})$ の導入によりCTのデータ収集は著 増し、MRI と同様に任意多断面良質な 3 次元画像、血管像が得られている。さ らに高次元画像臨床応用による手術支援システムの開発も試みられている。 本パネルディスッカションでは、MRU（MR尿路撮像法）、前立腺癌診断におけ るMRS（MRスペクトロスコピー）、CT 3 次元画像、エコー造影剤撮像法、さら に医用高次元画像について各演者に最新の画像技術と将来展望についても言及 していただく予定である。 